\title{
INFLUENCE OF THE GLYPHOSATE FoRmulations ON WetTABILITY AND Evaporation Time of DROPLets ON Different TaRgets ${ }^{1}$
}

\author{
Influência de Formulações de Glyphosate sobre Molhamento e Tempo de Evaporação de Gotas \\ em Diferentes Alvos
}

\author{
OLIVEIRA, R.B. ${ }^{2}$, DARIO, G. ${ }^{2}$, ALVES, K.A. ${ }^{3}$, and GANDOLFO, M.A. ${ }^{2}$
}

\begin{abstract}
Efficiency of weed control can be increased if the herbicide formulation provides higher target coverage and evaporation time that enable an adequate distribution of herbicide on the target plant, allowing the absorption to continue even after the droplets evaporation. The aim of this research was to assess the influence of glyphosate formulations on the wetted area and evaporation time of droplets on different targets. Tests were conducted with droplets sizing from $500 \mu \mathrm{m}$ containing three formulations of glyphosate (isopropylamine salt, ammonium salt and potassium salt) deposited on three surfaces, two leaves (Bidens pilosa and Cenchrus echinatus) and glass slides. Sequential images analyses were used to quantify the evaporation time and the wetted area. An experimental system was utilized that was composed of a droplet generator, a stereo microscope with a camera to capture images, as well as an environmental chamber controlled for temperature and relative humidity. The kind of glyphosate formulations and target surfaces are crucial in the wetted area and evaporation time. The isopropylamine salt decreased the wetted area and evaporation time when compared with ammonium salt and potassium salt for all the surfaces deposited on. Bidens pilosa allows an increased wetted area for all the glyphosate formulations when compared to Cenchrus echinatus and glass slides.
\end{abstract}

Keywords: evaporation time, wetted area, herbicide, application technology.

\begin{abstract}
RESUMO - A eficiência do controle das plantas daninhas pode ser aumentada se a formulação do herbicida proporcionar maior espalhamento e tempo de evaporação que possibilite adequada distribuição do herbicida sobre a planta alvo, permitindo que a absorção continue mesmo após a evaporação da gota. O objetivo desta pesquisa foi avaliar a influência de formulações de glyphosate sobre a área de molhamento e o tempo de evaporação de gotas em diferentes alvos. Gotas de 500 um de diâmetro contendo formulações de glyphosate (sal de isopropilamina, sal de amônia e sal potássico) foram depositadas em três superficies (Bidens pilosa, Cenchrus echinatus e lâmina de vidro). Imagens sequenciais foram usadas para quantificar a área de molhamento e o tempo de evaporação. Para essas avaliações, foram utilizados um gerador de gotas, um estereoscópio com câmera para captura de imagens e uma câmara climática de controle de temperatura e umidade relativa do ar. Verificou-se que a formulação de glyphosate e a superficie alvo são determinantes no molhamento e na evaporação. A formulação sal de isopropilamina promove menor área de molhamento e tempo de evaporação quando comparada às formulações sal potássico e sal de amônia para todas as superfícies. A planta daninha Bidens pilosa permite maior área de molhamento para as três formulações de glyphosate, em comparação com as superficies de Cenchrus echinatus e lâmina de vidro.
\end{abstract}

Palavras-chave: tempo de evaporação, área de molhamento, herbicida, tecnologia de aplicação.

Recebido para publicação em 7.4.2015 e aprovado em 13.4.2015.

Universidade Estadual do Norte do Paraná - UENP, Bandeirantes, PR, Brasil, <rone@uenp.edu.br>; ${ }^{3}$ UEL, Londrina, PR, Brasil.

Planta Daninha, Viçosa-MG, v. 33, n. 3, p. 599-606, 2015 


\section{INTRODUCTION}

Understanding the interaction between droplets containing different glyphosate formulations and the targets allows for better adequacy of the herbicide according to the weed species to be controlled.

The spray droplet behavior under the target shall initially determine the deposition, as well as impact and accumulation on the leaf surface before penetration and evaporation of the solution. The herbicide spray absorption and efficiency are directly related to the spreading and evaporation of the droplets applied and may be reduced if the active ingredient is not spread uniformly on the target (Xu et al., 2010).

The morphological diversity of the existing leaf surface among the plant species and the presence of leaf structures can greatly influence the adherence and deposition of spray droplets, as in herbicide absorption (Costa et al., 2005). Structural analyses of leaf surfaces have shown differences in the organization of the epicuticular waxes and changes in their structure after herbicide spraying associated with mineral oil (Mendonça, 2007). Therefore, there is an interplay between physical and chemical characteristics of the spray solution and the foliar surface, which can influence the retention of deposits on the plant species.

Glyphosate has become the most widely used herbicide in the world with the development of genetically modified crops resistant to the molecule, such as soybean, cotton, maize, canola, sugar beet and alfalfa (Dill et al., 2008), being marketed in different formulations, such as isopropylamine salt, ammonium salt and potassium salt.

Several studies report the effect of adjuvants added to the herbicide solution onto the droplets behavior after their deposition on the target (Zhu et al., 2008; Yu et al., 2009; $\mathrm{Xu}$ et al., 2010; Hunsche \& Noga, 2012). In this context, the investigation of the interaction among herbicides and targets is critical to assist in the proper choice of these herbicides application technology, to reduce evaporative losses and maximize scattering and, therefore, application efficiency.
The objective of this research was to assess the influence of glyphosate formulations on the wetting area and the droplets evaporation time in different targets.

\section{MATERIAL AND METHODS}

In this study, the behavior of droplets from three glyphosate formulations deposited on three target surfaces was assessed, being two natural and one artificial, using the methodology of analysis by images.

The experiment was done in a $3 \times 3$ factorial arrangement ( 3 formulations of glyphosate $\times 3$ target surfaces), totaling nine treatments (combination of factors), using a completely randomized design with five replications.

Droplets of $500 \mu \mathrm{m}$ in diameter containing glyphosate formulations (isopropylamine salt, ammonium salt and potassium salt) were deposited on three surfaces (Bidens pilosa, Cenchrus echinatus and glass slide). Sequential images were used to quantify the wetting area and the evaporation time. For these assessments were used a droplet generator, a stereo microscope (or stereoscopic microscope or dissecting microscope) with a camera for capturing images and an environmental chamber (also called climatic chamber or climate chamber) to control temperature and relative humidity.

The glyphosate herbicide formulations were isopropylamine salt, at $2.0 \mathrm{~L} \mathrm{ha}^{-1}$ (Roundup Original ${ }^{\circledR}$ ), ammonia salt, at $1.0 \mathrm{~kg} \mathrm{ha}^{-1}$ (Roundup $\mathrm{WG}^{\circledR}$ ), and potassium salt, at $1.4 \mathrm{~L} \mathrm{ha}^{-1}\left(\right.$ Zapp $\left.^{\circledR}\right)$, constituting the same amount of acid equivalent in all treatments. The concentrations in the spray solutions were measured considering the application rate of $100 \mathrm{~L} \mathrm{ha}^{-1}$.

The target surfaces used were two species of weeds: Cenchrus echinatus (common names southern sandspur, southern sandbur) and Bidens pilosa (many common names include black-jack, beggar-ticks, cobbler's pegs, and Spanish needle) and glass slide (artificial target), which are shown in Figures 1A, $\mathrm{B}$ and $\mathrm{C}$, respectively.

The leaves of the weed species used in the experiment were collected from plants 

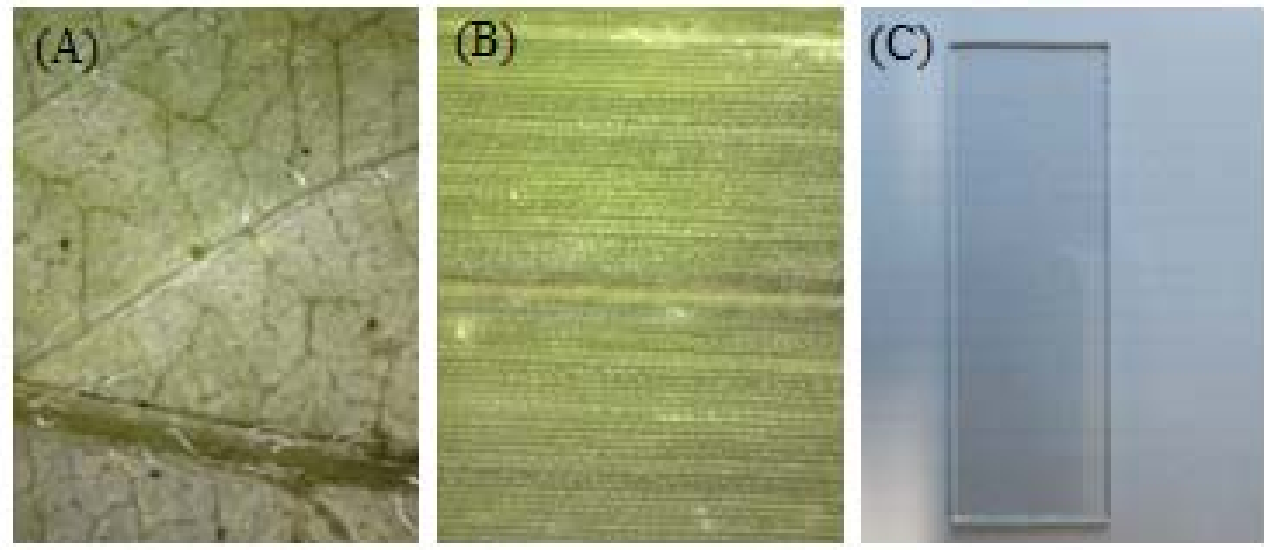

Figure 1 - Target surfaces used for deposition of droplets containing the different formulations of glyphosate herbicide. Bidens pilosa (A), Cenchrus echinatus (B) and glass slide (C).

sown in pots and when these reached the vegetative stage of five pairs of leaves for Bidens pilosa and four fully expanded leaves for Cenchrus echinatus.

For each of the prepared spray solutions (different glyphosate herbicide formulations), the surface tension was determined by the gravimetric method, considering the weight of droplets of distilled water as $72.6 \mathrm{mN} \mathrm{m}^{-1}$, according to the methodology used by Oliveira $\&$ Antuniassi (2012).

The wetting area and the time of evaporation, as well as the calibration of the generated droplets size, were determined under controlled conditions of temperature $28{ }^{\circ} \mathrm{C}\left( \pm 1.5^{\circ} \mathrm{C}\right)$ and relative humidity of $70 \%$ $( \pm 3 \%)$, using a climatic chamber with dimensions of $1.7 \times 1.5 \times 0.8 \mathrm{~m}$ in length, height and depth, respectively, with test section of $0.5 \times 1.5 \times 0.8 \mathrm{~m}$, constructed in a thermal insulating material (expanded PVC). Changes in relative humidity were done by a humidifier and a dehumidifier, and of the temperature by air conditioning and an infrared heater. The control system comprises temperature and humidity sensors with a precise measurement capability and automated by a programmable logic controller (PLC). The chamber is divided into two environments: environment 1: deposit of the equipment and air formation; and environment 2: test section. After the air was in balance in the condition of temperature and relative humidity desired in the test section, with the system closed, the tests were performed. The tests section contains a stereo microscope equipped with a high definition digital camera for a high-level viewing of the target, and a software for capturing, processing and measuring sequential images of the droplets.

The droplets were $500 \mu \mathrm{m}$ in diameter and produced by a droplet generator based on the droplet ejection time, air pressure and vacuum (Model Ultimus V, EFD Inc; East Providence, RI), connected by a flexible tube to a microsyringe measuring $7.3 \mathrm{~cm}$ long and $1.1 \mathrm{~cm}$ of internal diameter, with a capacity for $4.5 \mathrm{~mL}$ of liquid.

To calibrate the size of the droplets, 20 of them were deposited on spider web threads fixed on a holder, which allows them to retain their spherical shape in order to measure their diameter (Figure 2A). The time of expulsion, pressure and vacuum of the droplets generator is changed until the droplets formed have an average diameter of $500 \mu \mathrm{m}$, with a variation of $\pm 25 \mu \mathrm{m}$. This calibration was done for each of the solutions containing the glyphosate formulations, so that all the droplets were analyzed with the same size. The droplet on the spider web thread was visualized by a stereo microscope with $1.5 \times$ zoom and magnifications ranging from $10 \mathrm{x}$ by means of a combination of special lenses and eyepieces (Bel Engineering ${ }^{\circledR}$ ), coupled to a digital camera, creating Bitmap type images, with a resolution of $1260 \times 960$. The droplet diameter was measured in $\mathrm{mm}$, with the function line of the software Iscapture 


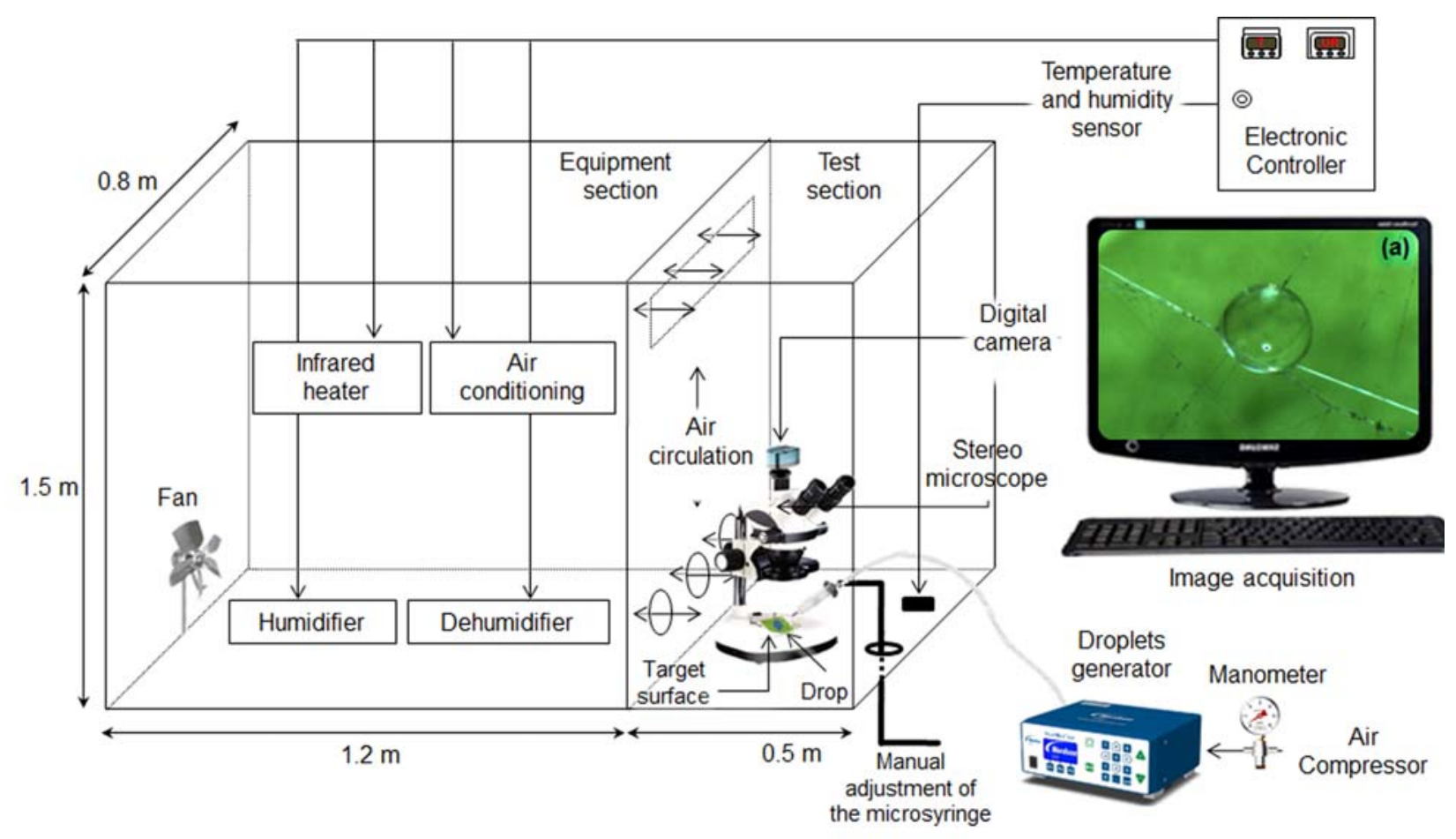

Figure 2 - A system developed to determine the evaporation and wettability in controlled temperature and relative humidity.

2.2.1 (SCIENON TECHNOLOGY CO. LTDA), which comes together with the camera used to capture the images. The program was calibrated with an image of a ruler of $0.01 \mu \mathrm{m}$ in the same magnification photographic objective lens and zoom used in image capture.

To study the wetting area and evaporation time, droplets of $500 \mu \mathrm{m}$ in diameter were deposited on the surfaces. From the droplet deposition starts the capture of sequential images with a high-level view of the droplet at 3 seconds intervals until total evaporation of its liquid, leaving only the solid parts of the spray solution on the surface. The droplet on the surface was visualized by a stereo microscope with zoom of $0.7 \mathrm{x}$ and magnifications in the range of $10 \mathrm{x}$ by means of a special combination of lenses and eyepieces (Bel Engineering ${ }^{\circledR}$ ) coupled to a digital camera, creating Bitmap type images, with a resolution of $1260 \times 960$.

The droplet wetting area was measured in $\mathrm{mm}^{2}$ with software Iscapture 2.2.1, which came with the camera used to capture the images, in which the edges of the droplets were delimited using the polygon function, and the droplet corresponding to the maximum area of each repetition was measured. The program was calibrated with an image of a ruler of $0.01 \mu \mathrm{m}$ in the same magnification photographic objective lens and zoom used in image capture. The evaporation time was measured by the time interval between the droplet deposition and the liquid part extinction, recorded by sequential images captured during evaporation. Thus, the evaporation time was calculated by counting the number of pictures multiplied by the time interval between shots, according to the methodology developed by Zhu et al. (2008).

The data were subjected to analysis of variance, and the means were compared by Tukey test at $5 \%$ probability.

\section{RESULTS AND DISCUSSION}

There was an interaction between the target surfaces and the types of glyphosate formulation for the wetting area and the evaporation time of the droplets (Table 1). This indicates that the process of spreading and evaporation of droplets is determined by both the physical and chemical properties of the 
herbicide formulation, as by the droplet deposition surface characteristics. There are also other factors that affect the droplets behavior after their deposition on the target. Hunsche \& Noga (2012) have stated that the use of adjuvants added to the agrochemical solution and the relative humidity change the distribution of herbicide residues on the target and their biological effectiveness.

The isopropylamine salt and ammonium salt formulations had a similar surface tension but differed in wettability (Figure 3A). All formulations have reduced surface tension compared to water as standard $\left(72.6 \mathrm{mN} \mathrm{m}^{-1}\right)$, but in a different magnitude. This indicates that the surface tension is one of the mechanisms that determine the droplet spreading on the target; however, it can not be used alone to assess the wettability capacity of an agrochemical solution, as it represents only one of the factors involved in this process. For a correct interpretation of the droplets behavior on the target, methods to directly assess the wettability of solutions droplets used in spraying must be employed. Hunsche $\&$ Noga (2012) and Costa et al. (2014) have not either established a direct link between the reduction of surface tension and increased droplet wettability of herbicide solutions and adjuvants applied on hydrophilic and hydrophobic surfaces. However, it is noteworthy that surface tension gradients of a solution can interfere with the distribution of solid waste of agrochemical solutions and alter absorption (Wang \& Liu, 2007).

The potassium salt and ammonium salt formulations, when applied to B. pilosa leaves, have shown greater wettability, while the isopropylamine salt formulation on
C. echinatus leaves and glass slide has shown less wettability (Figure 3B).

The spreading of the isopropylamine salt formulation droplets on the surfaces of C. echinatus and glass slide has shown no significant differences, being lower than the wettability obtained on the surface of Bidens pilosa (Figure 3B).

The surface of $B$. pilosa allowed greater wettability of the droplets in all glyphosate formulations, because of its leaf surface having branched ribs that facilitate the movement of the fluid. In the images, it can be seen that the droplet spread is greater towards the ribs forming flow channels of the solution on the leaf surface (Figure 4). The wettability is dependent on the leaf surfaces, where the morphological diversity among the weed species, such as trichomes, cuticle, ribs and waxes, can exert great influence on the spread of spray droplets and change the herbicide absorption (Iost \& Raetano, 2010).

The greater amount of wax present on the leaves adaxial surface of the species C. echinatus makes wettability difficult, always presenting a lower wettability regarding B. pilosa (Figure 4). The wax acts as a repellent to aqueous solutions deposited on leaf surfaces, making the wettability difficult (Wagner et al., 2003; Guo \& Liu, 2007; Holder, 2007; Xu et al., 2010).

The potassium salt formulation on surfaces of $C$. echinatus has shown higher evaporation time among all treatments and isopropylamine salt formulation has shown less evaporation time of the droplets on all deposition surfaces (Figure 5). In the sequence analysis of images of the droplets interaction with the leaf

Table 1 - Summary of the analysis of variance (ANOVA) for wetting area and evaporation time in the interaction among glyphosate formulations and target surfaces

\begin{tabular}{|c|c|c|c|c|c|c|}
\hline \multirow{2}{*}{ Source of variation } & \multicolumn{3}{|c|}{ Wettability area $\left(\mathrm{mm}^{2}\right)$} & \multicolumn{3}{|c|}{ Evaporation time (s) } \\
\hline & SS & MS & $\mathrm{F}$ & SS & MS & $\mathrm{F}$ \\
\hline Formulations & 24.62 & 12.31 & $32.04 *$ & 86975.64 & 43487.82 & 78.30* \\
\hline Surfaces & 55.65 & 27.83 & $72.42 *$ & 54412.22 & 27206.11 & 48.99* \\
\hline Formulations versus surfaces & 8.75 & 2.19 & $5.69 *$ & 23.99 & 5980.53 & $10.77 *$ \\
\hline Residue & 11.53 & 0.39 & & 16661.25 & 555.37 & \\
\hline CV (\%) & \multicolumn{3}{|c|}{22.71} & \multicolumn{3}{|c|}{21.10} \\
\hline
\end{tabular}

$\mathrm{CV}$ - Coefficient of variation; * significant at $5 \%$ probability by F-test. 

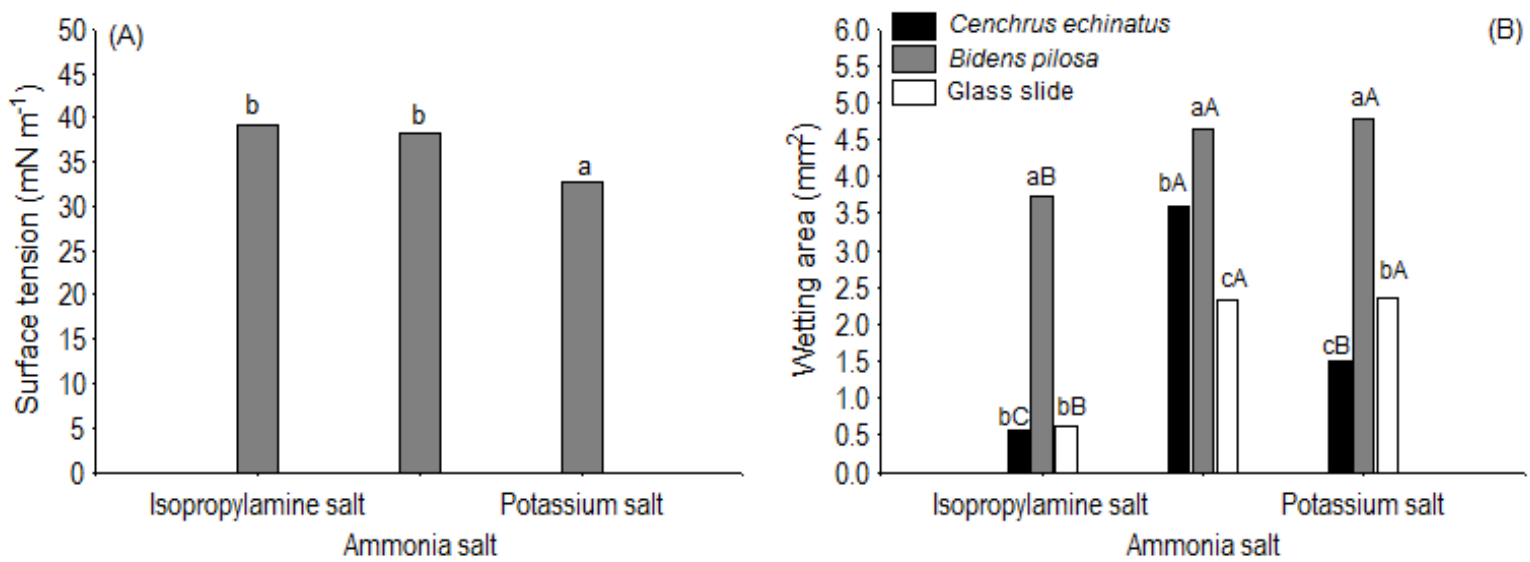

Means accompanied by the same letters, lowercase for the same glyphosate formulation and uppercase for the same droplet deposition surface, do not differ significantly at $5 \%$ probability by Tukey test. Least significant difference (LSD) $=0.76$.

Figure 3 - Surface tension, $\mathrm{mN} \mathrm{m}^{-1}$, (A) and wettability area, $\mathrm{mm}^{2}$, (B) of droplets measuring $500 \mu \mathrm{m}$ in diameter, arising from glyphosate formulations deposited on three target surfaces at $28{ }^{\circ} \mathrm{C}$ temperature and $70 \%$ relative humidity.

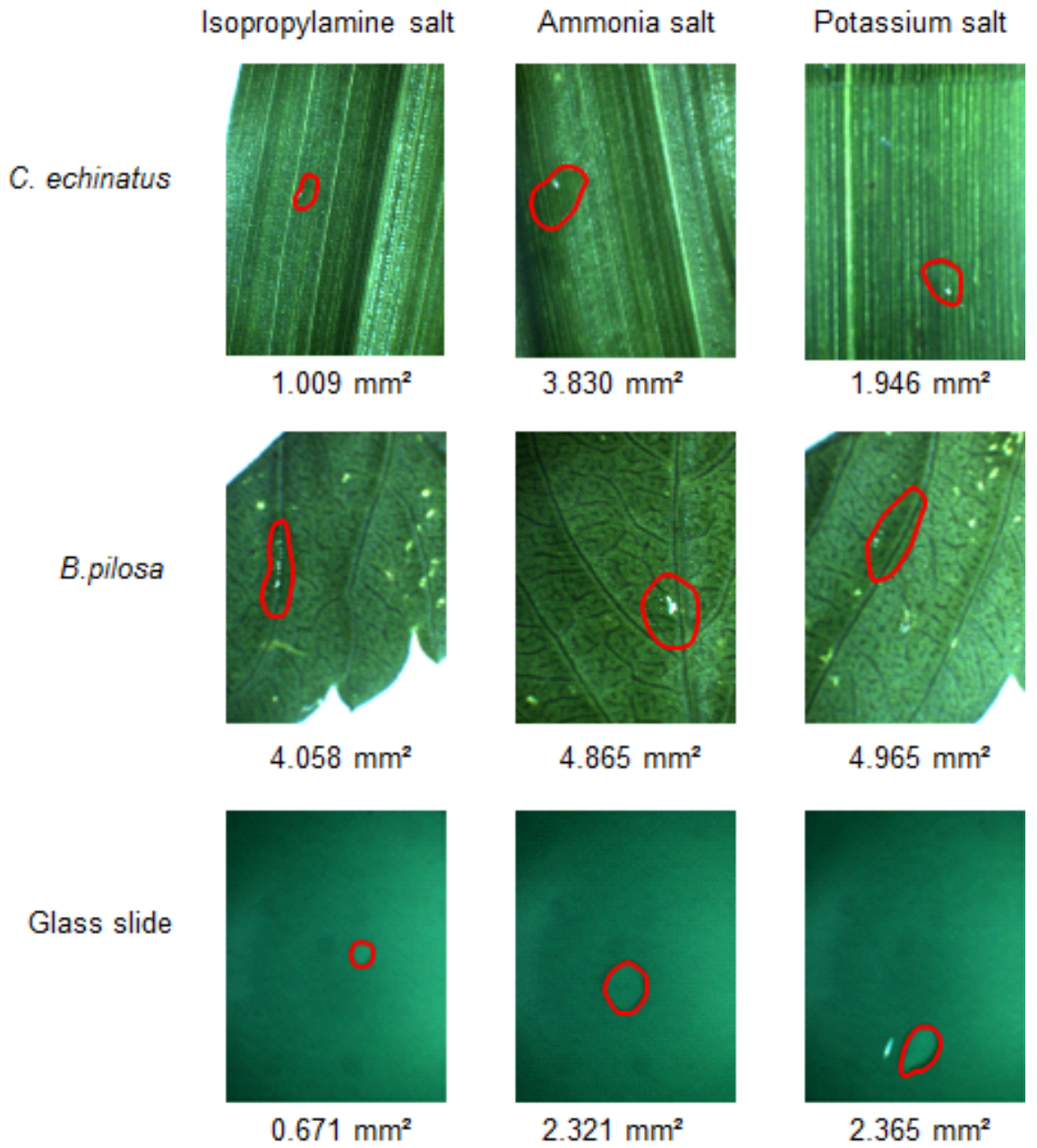

Figure 4 - Maximum wettability area $\left(\mathrm{mm}^{2}\right)$ of droplets measuring $500 \mu \mathrm{m}$ in diameter containing solutions of different glyphosate formulations deposited on three target surfaces at $28{ }^{\circ} \mathrm{C}$ temperature and $70 \%$ relative humidity. 
surface it is possible to observe the longevity of the spray droplets and their wettability; this wettability intensity, over time, can contribute to increase the absorption and penetration of active ingredients and also reduce the formation of crystals. When the liquid of the droplet evaporates, the herbicide foliar absorption is reduced, and the formed crystals can be removed from their place by the impact of wind, decreasing their efficiency (Yu et al., 2009; Glass et al., 2010).

The differences in evaporation time among the glyphosate formulations may be due to the presence of other ingredients described in the composition of the herbicidal formulations, which modifies the droplet behavior on the target by increasing or decreasing the evaporation time.

The leaf surface of C. echinatus remained wet longer compared to other surfaces in all formulations, except B. pilosa with isopropylamine salt, where there was no significant difference (Figure 5). The higher evaporation time of the droplets deposited on the surface of $C$. echinatus can be explained by the lower spreading occurred on these surfaces, i.e., the evaporation time is inversely proportional to the spreading: the higher the scattering, the higher the surface exposed to

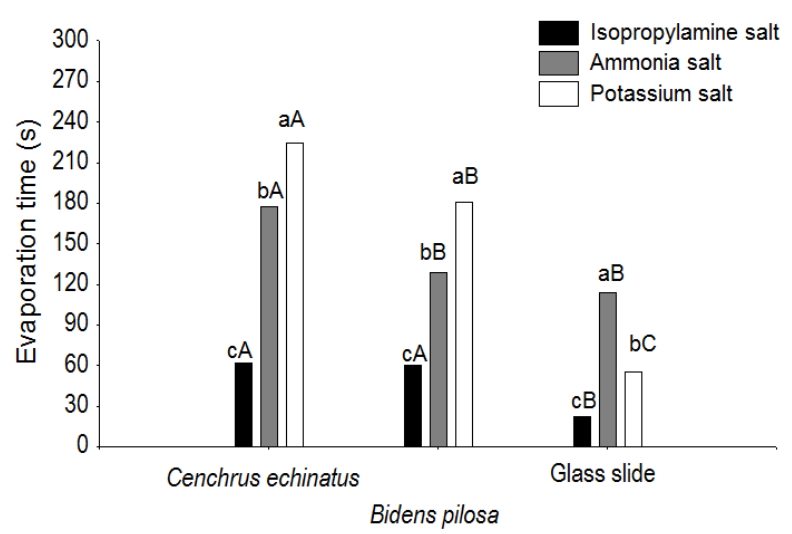

Means accompanied by the same letters, lowercase for the same glyphosate formulation and uppercase for the same droplet deposition surface, do not differ significantly at $5 \%$ probability by Tukey test. Least significant difference $(L S D)=61.84$.

Figure 5 - Evaporation time of droplets measuring $500 \mu \mathrm{m}$ in diameter, from different glyphosate formulations deposited on three target surfaces at $28^{\circ} \mathrm{C}$ temperature and $70 \%$ relative humidity. the evaporation. Gimenes et al. (2013), in soybean leaves, have also observed this inverse ratio. Zhu et al. (2008) have observed that the evaporation time of droplets deposited on hydrophobic surfaces was greater and less scattering occurred when compared to the hydrophilic surface, where there was greater scattering area.

In the glass slide surface, the relationship between the evaporation time and the wetting area of the droplets was not inversely proportional as on the leaf surface of $B$. pilosa, and $C$. echinatus, with the exception of those surfaces with the isopropylamine salt formulation. The glass slide showed the lowest evaporation time of the droplets in relation to leaf surfaces, in all glyphosate formulations, but has not shown a higher wetting area, which would justify the shorter evaporation time. This behavior may be due to the difference between the heat capacity of the glass slide and the plant surfaces. The glass slide heats up more rapidly when placed in the climatic chamber used in the study, thus accelerating the evaporation rate of the droplets deposited on it.

The artificial target (glass slide) underestimated the evaporation time of the droplets deposited for the potassium salt and ammonium salt formulations in relation to the surfaces of Cenchrus echinatus and Bidens pilosa. In this case, the glass slide did not represent precisely what happened to the weed species; however, they are widely used to assess the quality and quantity of deposit in sprays, as well as losses due to drift, often due to the practicality of use and the limitations found in the use of natural targets, but they have the advantage of the fact of not changing the results because of the morphological and physiological changes in the natural targets. A study about deposition by spectrophotometry has concluded that the presence of contaminants on glass plates (artificial target) is lesser when compared to the ones on the leaves (natural target) because of the reduced exposure time to field conditions (Koch \& Knewitz, 2006).

The methodology used in this research, sequential analysis of droplets images, has contributed to the understanding of the physical processes that occurred due to the 
interaction among glyphosate formulations and the leaf surfaces, which may be decisive in efficiency and loss reduction of the formulations.

\section{ACKNOWLEDGMENT}

To Fundação Araucária (The Araucaria Foundation is an agency for the development of research in the Brazilian state of Paraná), for the scholarship granted to the second author.

\section{LITERATURE CITED}

COSTA, N. V. et al. pH foliar e deposição de gotas de pulverização em plantas daninhas aquáticas: Brachiaria mutica, Brachiaria subquadripara e Panicum repens.

Planta Daninha, v. 23, n. 2, p. 295-304, 2005.

COSTA, N. V. et al. Tensão superficial e área de espalhamento de gotas de soluções com herbicidas e adjuvantes em folhas de Conyza canadensis. Sci. Agr. Paranaensis - SAP, v. 13, n. 2, p. 161-170, 2014

DILL, G. M.; CAJACOB, C. A.; PADGETTE, S. R. Glyphosate-resistant crops: adoption, use and future considerations. Pest Manag. Sci., v. 64, n. 4, p. 326-331, 2008.

GIMENES, M. J. et al. Dispersion and evaporation of droplets amended with adjuvants on soybeans. Crop Protec., v. 44, n. 4, p. 74-90, 2013.

GUO, Z. G.; LIU, M. Biomimic from the superhydrophobic plant leaves in nature: Binary structure and unitary structure. Plant Sci., v. 172, n. 6, p. 1103-1112, 2007.

HOLDER, C. D. Leaf water repellency of species in Guatemala and Colorado (USA) and its significance to forest hydrology studies. J. Hydrol., v. 336, n. 1, p. 147-154, 2007.

HUNSCHE, M.; NOGA, G. Effects of relative humidity and substrate on the spatial association between glyphosate and ethoxylated seed oil adjuvants in the dried deposits of sessile droplets. Pest Manag. Sci., v. 68, n. 2, p. 231-239, 2012.
IOST, C. A. R.; RAETANO, C. G. Tensão superficial dinâmica e ângulo de contato de soluções aquosas com surfatantes em superfícies artificiais e naturais. Eng. Agríc., v. 30, n. 4, p. 670-680, 2010.

KOCH, H.; KNEWITZ, H. Methodology and sampling technique of spray deposit and distribution measurement in orchards. Nachrichtenblatt Deutschen Pflanzenschut., v. 58, n. 1, p. 6-9, 2006.

MENDONÇA, C. G.; RAETANO, C. G.; MENDONÇA, C. G. Tensão superficial estática de soluções aquosas com óleos minerais e vegetais utilizados na agricultura. Eng. Agríc., v. 27, p. 16-23, 2007. (Número Especial)

OLIVEIRA, R. B.; ANTUNIASSI, U. R. Caracterização física e química e potencial de deriva de caldas contendo surfatantes em pulverizações agrícolas. Energia Agric., v. 27, n. 1, p. 138-149, 2012.

GLASS, C. R. et al. Recent advances in computational fluid dynamics relevant to the modelling of pesticide flow on leaf surfaces. Pest Manag. Sci., v. 66, n. 1, p. 2-9, 2010.

WAGNER, P. et al. Quantitative assessment to the structural basis of water repellency in natural and technical surfaces. J. Exp. Bot., v. 54, n. 385, p. 1295-1303, 2003.

WANG, C. J.; LIU, Z. Q. Foliar uptake of pesticides: present status and future challenge. Pest. Biochem. Physiol., v. 87, n. 1, p. 1-8, 2007.

XU, L. et al. Adjuvant effects on evaporation time and wetted area of droplets on waxy leaves. Trans. ASABE, v. 53, n. 1, p. 13-20, 2010.

YU, Y. et al. Evaporation and deposition coverage area of droplets containing insecticides and spray additives on hydrophilic, hydrophobic and crabapple leaf surfaces. Trans. ASABE, v. 52, n. 1, p. 39-49, 2009.

ZHU, H. et al. Influence of spray additives on droplet evaporation and residual patterns on wax and wax-free surfaces. St Joseph, MI: ASABE, 2008. (Trans. ASABE, paper 083752) 